\title{
Teaching Styles, Learning Styles and the ESP Classroom
}

\author{
Lee Mei Ph'ng1,* \\ ${ }^{1}$ Department of Languages, Center for Languages and Human Development Universiti Teknikal Malaysia Melaka, Hang Tuah Jaya, \\ 76100 Durian Tunggal, Melaka, Malaysia
}

\begin{abstract}
Learner diversity that exists in the classroom plays a role in influencing the teaching and learning process in the classroom. It should be acknowledged in order for the teaching and learning process to be a meaningful and effective process. Thus, this study examined the learning styles preference of engineering students and the teaching styles preferences of their Technical Communication lecturers. The study also looked at whether the students' learning styles preferences were influenced by their field of study, gender and ethnic backgrounds. Felder and Solomon's Index of Learning Styles was administered to 588 engineering students while Grasha and Riechmann-Hruska's Teaching Style Survey was administered to 10 Technical Communication lecturers. The findings revealed that the students have a marked preference for the visual learning style but balanced preferences for the other learning styles dimensions. The students' field of study, gender and ethnic backgrounds did not seem to influence the students' learning styles preferences. As for their Technical Communication lecturers, they seem to favour the student-centered teaching approach. All the data support the notion of adopting a balanced teaching approach in the Technical Communication classroom.
\end{abstract}

\section{Introduction}

Learners and educators are becoming equally diverse. The diversity that occurs among the students means that learners will react differently to their lecturers based on their learning styles preferences [1]. In addition, diversity in teaching and learning styles preferences would result in matches and mismatches between the lecturers' teaching styles and students' learning styles. Learning styles refer to students' preferred learning approaches for all learning situations while teaching styles refer to the lecturers' behaviour, beliefs and selected instructional methods used to present lessons to students [2]. There are researchers who believe that lecturers' teaching styles should match the students' learning styles for effective learning to occur, ensure student motivation and achievement [3-5].

However, the mismatches which are bound to happen may be helpful to students to stretch their learning experiences as this would mean adopting their non-preferred learning styles [6]. In other words, all types of learners still need to be addressed [1]. This study believes that a balanced teaching approach that uses various teaching approaches should be adopted for the classroom.

Variety in instructional approaches can be used to address student diversity [7]. Addressing the preferred learning styles of the students acknowledges the uniqueness and differences of the students [8-9]. The different learning styles of students indicate that they have different strengths and preferences in the ways they absorb and process information [10-12]. In addition, students' learning styles have been identified as one of the factors that influence the quality of learning [13-14].

Emphasis has been placed on learning styles and teaching styles in engineering education $[8,15]$. One reason is lecturers' teaching styles preferences and students' learning styles preferences do influence the teaching and learning process [16-17]. Studies have been conducted to identify the learning styles preferences of engineering students with regards to their fields of study [18-20], gender [21-23] and ethnic backgrounds [24-26]. Researchers have also looked at the teaching styles of language lecturers [27-28].

Shindler stated, five principles for succeeding with student learning diversity can be used as a guide for the teaching and learning process [29]. Two of the principles included the identification of the teaching styles preferences of educators and the learning styles preferences of learners. Thus, this study attempted to profile the student diversity of Universiti Teknikal Malaysia Melaka (UTeM) engineering undergraduates in terms of their learning styles preferences according to their field of study, gender and ethnic background. It also sought to examine the teaching styles of their Technical Communication lecturers.

The Technical Communication classrooms are English for Specific Purposes (ESP) in nature and thus knowledge of the students' learning styles preferences may be useful information for the lecturers when planning their lessons. As highlighted by Sinha and Sadorra, the ability to use a variety of in-class activities

\footnotetext{
${ }^{1}$ Corresponding author: meiphng@utem.edu.my
} 
is one characteristic central to an ESP teacher for creating a climate for learning [30]. Having an understanding of the learning styles of students and also the tendency the lecturers tend to teach will be able to assist in the creation of the in-class activities in the technical communication classroom.

\section{Method}

\subsection{Sampling}

This study involved 588 engineering students from four engineering faculties namely the Faculty of Electrical Engineering (FKE), Faculty of Electronics and Computer Engineering (FKEKK), Faculty of Manufacturing Engineering (FKP) and Faculty of Mechanical Engineering (FKM). They were from 16 out of the 17 degree programs comprising 146 students from FKE; 163 students from FKEKK; 128 students from FKM and 151 students from FKP. The respondents comprised of 300 male students and 288 female students. 487 of them were Bumiputera respondents, 88 of them Chinese and 13 of them Indians. The sample also included ten Technical Communication lecturers.

\subsection{Research Instruments}

Felder and Solomon's Index of Learning Styles was employed to determine the students' learning styles preferences. This instrument was chosen for this study as it was designed with engineering students in mind and various studies have discussed its reliability and validity [11, 21-32]. It was administered and the data analysed to identify students' learning styles preference according to their field of study, gender and ethnic backgrounds.

There are 44 questions in the Index of Learning Styles. Respondents were required to choose an answer from two options, 'a' or ' $b$ '. For example, one of the questions asks "I understand something better after I'... and the options given are (a) try it out and (b) think about it in detail. Learners are categorised according to eight learning styles preferences (active, reflective, sensing, intuitive, visual, verbal, sequential and global) which are further categorised into four learning styles dimensions namely the active-reflective, sensing-intuitive, visual-verbal and sequential-global dimensions.

Active learners, for example, learn by doing and working with others. Reflective learners, on the other hand, prefer to work alone on the material. Sensing learners are generally oriented towards facts while intuitive learners are generally oriented towards theories. Visual learners learn more from things they see while verbal learners learn more from written and spoken words. As sequential learners, they prefer to learn step by step compared to global learners who prefer to learn in a holistic manner.

The second research instrument was the Teaching Style Survey by Anthony F. Grasha and Sheryl
Riechmann-Hruska's, which was used to determine the teaching styles of the Technical Communication lecturers. The Teaching Style Survey was chosen as it was based on a model that was derived from thematic analysis of the universal teaching styles found in college education [33]. His analysis focused on how and why educators taught in particular ways and universal qualities of educators from multiple disciplines and classroom environments. He suggested that every educator has elements of every teaching style in the model but in varying degrees [33]. The Teaching Style Survey classifies one's teaching styles preferences into five categories namely the formal authority (sets standards and defines acceptable ways of doing things), delegator (develops students' ability to function autonomously), facilitator (guides and directs by asking questions, exploring options, suggesting alternatives), personal model (teaches by illustration and direct example) and expert styles (transmitter of information) [34]. There are 40 questions in the Teaching Style Survey and the respondents were required to rank their responses based on a 5 -point Likert scale ( $1=$ strongly disagree, $2=$ moderately disagree, $3=$ undecided, 4= moderately agree, 5 = strongly agree).

\subsection{Data Analysis}

The first stage involved manual calculation of the scores before they could be input into SPSS for analysis to determine the distribution of the respondents' learning styles preferences. The basis for the manual calculation is based on the calculation by Felder.

The Index of Learning Styles has 44 questions and each question has two options i.e. 'a' or 'b'. Let's take the visual-verbal learning style dimension as an example. The 'a' options for these questions refer to the visual style while the ' $b$ ' options refer to the verbal style. In determining a student's learning style preference, the following method was used. For example, if a student chose 8 ' $a$ ' and 3 ' $b$ ' options, he/she will be described as inclining towards the visual learning style based on the calculation of (8a-3b $=5 a$ ) as there are more ' $a$ ' options. Once the scores have been manually calculated, the scores were recorded and entered into SPSS Ver. 19 for statistical analysis to determine the distribution of the students' learning styles preferences for the following dimensions:

- active-reflective dimension,

- $\quad$ sensing-intuitive dimension,

- visual-verbal dimension

- sequential-global dimension.

Taking the visual-verbal dimension for example, students are categorised as either visual or verbal learners in Felder's model. This study however considers the possibility that students may have balanced preferences for the particular learning style dimension. 
Since the paper version of the Teaching Style Survey was used in this study, the researcher manually calculated the scores to determine the individual teaching styles of the ten lecturers. The strength of the lecturers' preferences was determined based on the calculation provided by Grasha [33]. Their preferences were categorised as either low, moderate or high.

\section{Results}

Data analysis revealed that students were generally inclined towards having balanced preferences for the active-reflective, sensing-intuitive and sequentialglobal learning styles dimensions. However, there was an inclination towards the visual learning styles for the visual-verbal learning styles dimension (Table 1).

\subsection{Learning Styles Preferences According to Field of Study}

A reasonably evenly distributed sample population was selected from each faculty for the study (Table 2 ). The findings revealed that the patterns of preference of students from all faculties were fairly similar. All groups showed preference for the visual learning styles and balanced preferences for the active-reflective, sensing-intuitive and sequential-global learning styles dimensions.

\subsection{Learning Styles Preferences According to Gender}

An approximately equal number of male and female respondents took part in the study (Table 3). The analysis showed the students as having fairly similar patterns of preferences according to their gender. The students had a marked preference for the visual learning styles and balanced preferences for the activereflective, sensing-intuitive and sequential-global learning styles dimensions. From the findings it appeared that there were no marked differences in learning styles across gender.

Table 1: General Learning Styles Preferences of UTeM Students (\% Count)

\begin{tabular}{|c|c|c|c|c|c|c|c|c|c|c|c|}
\hline Act. & Bal. & Ref. & Sns. & Bal. & Int. & Vis. & Bal. & Vrb. & Seq. & Bal. & Glo. \\
\hline 23 & 68 & 9 & 16 & 71 & 13 & 64 & 34 & 2 & 17 & 71 & 12 \\
\hline
\end{tabular}

Act. $=$ Active, Ref. $=$ Reflective, Sns. $=$ Sensing, Int. $=$ Intuitive,

Vis. = Visual, Vrb. = verbal, Seq. $=$ Sequential, Glo. $=$ Global, Bal. $=$ Balanced

Table 2: Learning Styles Preferences of UTeM Students: According to Field of Study (\% Count)

\begin{tabular}{|c|c|c|c|c|c|c|c|c|c|c|c|c|}
\hline Fac & Act & Bal & Ref & Sns & Bal & Int & Vis & Bal & Vrb & Seq & Bal & Glo \\
\hline $\begin{array}{c}\text { FKE } \\
(\mathrm{N}=146)\end{array}$ & 27 & 66 & 7 & 15 & 69 & 16 & 61 & 37 & 2 & 16 & 77 & 7 \\
\hline $\begin{array}{c}\text { FKEKK } \\
(\mathrm{N}=163)\end{array}$ & 17 & 71 & 12 & 20 & 64 & 16 & 60 & 38 & 2 & 25 & 67 & 8 \\
\hline $\begin{array}{c}\text { FKM } \\
(\mathrm{N}=128)\end{array}$ & 27 & 64 & 9 & 8 & 77 & 15 & 70 & 28 & 2 & 14 & 68 & 18 \\
\hline $\begin{array}{c}\text { FKP } \\
(\mathrm{N}=151)\end{array}$ & 23 & 69 & 8 & 20 & 74 & 6 & 65 & 33 & 2 & 12 & 74 & 14 \\
\hline
\end{tabular}

Fac $=$ Faculty, Act. = Active, Ref. $=$ Reflective, Sns. = Sensing, Int. = Intuitive,

Vis. $=$ Visual, Vrb. $=$ verbal, Seq. $=$ Sequential, Glo. $=$ Global, Bal. $=$ Balanced

Table 3: Learning Styles Preferences of UTeM Students: According to Gender (\% Count)

\begin{tabular}{|l|c|c|c|c|c|c|c|c|c|c|c|c|}
\hline Gender & Act & Bal & Ref & Sns & Bal & Int & Vis & Bal & Vrb & Seq & Bal & Glo \\
\hline $\begin{array}{l}\text { Male } \\
(\mathrm{N}=300)\end{array}$ & 24 & 66 & 10 & 14 & 63 & 13 & 65 & 34 & 1 & 13 & 73 & 14 \\
\hline $\begin{array}{l}\text { Female } \\
(\mathrm{N}=288)\end{array}$ & 23 & 69 & 8 & 19 & 69 & 12 & 63 & 35 & 2 & 21 & 69 & 10 \\
\hline
\end{tabular}

Act. $=$ Active, Ref. $=$ Reflective, Sns. $=$ Sensing, Int. $=$ Intuitive,

Vis. = Visual, Vrb. = verbal, Seq. $=$ Sequential, Glo. $=$ Global, Bal. $=$ Balanced

\subsection{Learning Styles Preferences According to Ethnic Background}

The Indian respondents were excluded from the analysis due to their relatively small number $(n=13)$. 
The analysis highlighted fairly similar learning styles preferences for both groups of respondents (Table 4). The students had a distinct preference for the visual learning styles and were balanced in their preferences for the active-reflective, sensing-intuitive and sequential-global learning styles dimensions. From the findings it appeared that there were no marked differences in learning styles across the students' ethnic background.

\subsection{Lecturers' Teaching Styles Preferences}

Ten lecturers comprising of six lecturers and four language teachers participated in this part of the study. Their preferences are shown in Table 5. L8 was the only lecturer who had a high preference for the delegator style. Five lecturers (L3, L4, L5, L6 and L7) had preference for the facilitator teaching style followed by the expert style (L1, L2 and L5). Incidentally, L8 was the only lecturer who had a high preference for the delegator teaching style which was also the least prevalent teaching style while L9 was the only lecturer who recorded a low preference for her teaching style. Interestingly, majority of the lecturers (eight lecturers) had moderate teaching style preferences.

Table 4: Learning Styles of UTeM Students: According to Ethnic Background (\% Count)

\begin{tabular}{|c|c|c|c|c|c|c|c|c|c|c|c|c|}
\hline EB & Act & Bal & Ref & Sns & Bal & Int & Vis & Bal & Vrb & Seq & Bal & Glo \\
\hline $\begin{array}{c}\mathrm{B} \\
(\mathrm{N}=487 \\
)\end{array}$ & 25 & 67 & 8 & 14 & 72 & 14 & 64 & 34 & 2 & 16 & 71 & 13 \\
\hline $\begin{array}{c}\mathrm{C} \\
(\mathrm{N}=88)\end{array}$ & 12 & 74 & 14 & 31 & 61 & 8 & 62 & 38 & 0 & 17 & 72 & 11 \\
\hline
\end{tabular}

$\mathrm{EB}=$ Ethnic Background, $\mathrm{B}=$ Bumiputera, $\mathrm{C} .=$ Chinese, Act. $=$ Active, Ref. $=$ Reflective, Sns. = Sensing, Int. = Intuitive, Vis. $=$ Visual, Vrb. = verbal,

Seq. $=$ Sequential, Glo. $=$ Global, Bal. $=$ Balanced

Table 5: Lecturers' Teaching Styles Preferences

\begin{tabular}{ccc}
\hline Lecturer & Teaching Styles Preference & Strength of score \\
\hline L1 & Expert & Moderate \\
L2 & Expert & Moderate \\
L3 & Formal Authority \& Facilitator & Moderate \\
L4 & Personal Model \& Facilitator & Moderate \\
L5 & Expert \& Facilitator & Moderate \\
L6 & Facilitator & Moderate \\
L7 & Facilitator & Moderate \\
L8 & Delegator & High \\
L9 & Personal Model & Low \\
L10 & Personal Model & Moderate \\
\hline
\end{tabular}

\section{Discussion}

One of the objectives of this study was to profile UTeM engineering undergraduates in terms of their learning styles preferences. In addition, this study sought to determine whether the students' field of study, gender and ethnic background influenced their learning styles preferences. Analysis revealed the students had a marked preference for the visual learning styles but generally balanced preferences for the active-reflective, sensing-intuitive and sequentialglobal learning styles dimensions.

These findings matched previous work done on the learning styles of engineering students in the sense that they are similar in their preferences for the visual learning styles $[20,35-36]$. The difference between this study and those of previous researchers was that this study looked at the students' learning styles preferences for every learning styles dimension by determining whether the students indicated any balanced learning styles preferences for a particular learning style dimension. For example, previously reviewed studies usually identified whether students have preference for the active or reflective learning style. This study takes into consideration students may also have balanced preferences for every learning style dimension as well.

This study also looked at their preferences according to gender and revealed similar results to previous studies in the sense that both groups of

respondents were similar in their marked preferences for the visual learning styles. Palou found similar findings where the respondents had clear preferences for the visual learning styles. The findings of this study have shown that the students had balanced preferences for the other three learning styles dimensions [21].

This study also focused on the students' learning styles preferences according to their ethnic backgrounds. It only looked at the learning styles 
preferences of Bumiputera and Chinese students due to the small number of Indian respondents. The students had a marked preference for the visual learning styles and were similar in terms of their balanced preferences for the other three learning styles dimensions. This finding was similar to their preferences for these dimensions according to their field of study and gender. These findings were both a contrast and similarity to Zualkernan et al.'s cross-cultural comparison of students' learning styles preferences which revealed engineering students as having preferences for the active, sensing, visual and sequential learning styles [37].

UTeM engineering students did have a similar marked preference for the visual learning style as other engineering students regardless of their field of study, gender or ethnic background. However, the UTeM students generally had balanced preferences for the other three learning styles dimensions regardless of their field of study, gender or ethnic background. Similarly, studies on engineering students [21-22] and non-engineering students $[24,26]$ proved that field of study, gender and ethnic background had minimal effect on the students' learning styles preferences.

This study also sought to examine the teaching styles preferences of the Technical Communication lecturers. This was deemed as necessary as lecturers' teaching styles partly determines engineering students' success in their engineering class [38]. Thus, doing so can indicate whether these Technical Communication lecturers have teaching styles preferences which are inclined towards teacher-centred teaching or studentcentred teaching. For example, lectures and demonstrations are examples of teacher-centred approaches while lab activities and learning centres are student-centred approaches [39].

The findings illustrated that the dominant preferred teaching styles was the facilitator teaching styles as it was preferred by five of the lecturers. The least preferred teaching style was the delegator teaching styles as it was preferred by only one of the lecturers. Interestingly, the findings appeared to be partially similar to Juliawati's study which revealed that English lecturers preferred the facilitator, personal model and delegator teaching styles [28]. The findings of the study also appeared to be contradictory to that of Liu et al. who identified language instructors as favouring the teacher-centred style [27].

Based on the discussion above, the findings can be used to enhance the teaching and learning process in the Technical Communication classroom. For example, lecturers should create sufficient opportunities for interaction in the classroom. Another factor lecturers should take note is that some students are shy and they prefer the lecturers to begin interacting with the students. In addition, although preference for classroom interaction is usually associated with active learners, it can encourage reflective learners (who prefer to work alone) to be out of their comfort zones and expand their learning experiences.

Besides that, opportunities for interaction can be created in the classroom by encouraging the students to ask questions or getting the students to report to the lecturer regarding their progress in doing their written assignments, particularly the technical report. This would be in line with the active learners who prefer interaction. As for the reflective learners, they will be encouraged to speak. For example, the students can be encouraged to meet the lecturer group by group. This way, they get to have personal interaction with the lecturer and address issues that may have arose when they were doing their assignments. This also fosters lecturer-student relationship. Besides that, language games on the grammar component can be conducted to encourage class interaction. Besides allowing the students to check their understanding of the topic, it can serve as a break from the routine grammar exercises and add the element of fun into the classroom. Getting students to work together also encourages the development of the teamwork soft skill.

In line with the constructivism view of teaching which calls for the lecturer to play the role as a facilitator, students should be allowed to take charge of their learning at some point in time. For example, the students can be allowed to choose their own topic for their assignments. Doing so allows them to relate their interests to their assignments and gives them room to explore their true potential. This will encourage the sensing learners who have preference learning facts and apply the knowledge they have learnt. The intuitive learners may have preference for the learning of the theoretical aspects of things but doing so encourages them to stretch their learning experiences by making them look for facts and learn to apply the knowledge.

Lecturers can provide students with the overview of the course or assignments before introducing the lessons step by step. This will benefit both students who prefer the global style (course overview) and sequential style (learning step by step). The lecturers can also provide the students with mindmaps of the lessons or concepts being taught.

In addition, lecturers can incorporate the use of examples in their lessons. For example, when conveying the expectations for the coursework, lecturers can show samples of good coursework done by previous students. This sets a benchmark for the kind of work expected from the students and indirectly encourages them to work towards producing a good piece of work. Another way for using examples would be to show the students videos related to the lessons. Examples include video recordings of meetings, presentations and job interview tips for students' reference. With regards to the sensing-intuitive learning style dimension, the learners can pick out the dos and don'ts related to meetings, presentations and job interviews. These videos can be used to attract the students' attention (visual-verbal learning style dimension). 


\section{Conclusion}

The success of the teaching and learning process depends on various factors which include the classroom environment, suitability of the venue and student motivation. The roles played by lecturers and students are also of equal importance towards the creation of a successful and meaningful teaching and learning process. While the lecturers may have their own teaching styles preferences and the students have their own learning styles preferences, they have their own roles to play. From the lecturers' perspective, they should consider the students' learning needs when designing their lessons. Thus, the choice depends on lecturers to understand the learning styles preferences of their students. Lessons which have a combination of all modes of learning are believed to be effective. Such lessons also become better avenues for students who have different learning styles to learn [40].

The findings have indicated that UTeM engineering students have a marked preference for the visual learning styles and balanced preferences for the other three learning styles dimensions. The findings also showed that the students' field of study, gender and ethnic background did not appear to influence the students' learning styles preferences. Secondly, they also indicated the students' learning styles preferences were generally inclined towards the balanced preferences. Their Technical Communication lecturers, on the other hand, generally favoured the studentcentred approach.

Thus, the findings seem to point to the possibility of having a balanced teaching approach for the Technical Communication classroom [41]. A balanced teaching approach could improve student learning [42]. Having a balanced teaching approach means there should be variety in the teaching activities in order to maintain student interest. This integration of a variety of teaching styles is also a characteristic of studentcentred teaching [43-44]. Doing so meets the needs of certain learning styles favoured by the students. It simultaneously encourages students to use learning styles less favoured by them as a way to stretch their learning abilities $[7,45]$. Such variety widens the students' learning experiences [46].

Thus, it is hoped that the findings and suggestions made in the study will be viewed as supporting information in effort to enhance the teaching and learning in the Technical Communication classrooms and for staff development purposes. When lecturers better understand their students and in the context of this study via their learning styles preferences, it allows lecturers to reach out to their students.

The author would like to thank Universiti Teknikal Malaysia Melaka for supporting this research.

\section{References}

1. D. M. Jepsen, M. M. Varhegyi, S. T. T., Edu. Train., 57(5), 575-587 (2015)
2. M. P. Lee, Students' preferences and perceptions of teaching styles and learning styles in an ESP context at a Malaysian technical university, (Doctoral Dissertation, Universiti Kebangsaan Malaysia, Malaysia, 2014)

3. K. S. Mak, WAHANA Akademik, 1(1), 58-67 (2002)

4. A. Briggs, (PhD Thesis, Walden University, 2003)

5. L. Bostrom, L. M. Lassen, Edu. Train., 48(2/3), 178-189 (2006)

6. M. Zhou, International Education Studies, 4(1), 73-77 (2011)

7. P. R. Durben, D. M. Byrd, Methods for effective teaching: Meeting the needs of all students. (United States of America: Pearson Education Inc., 2010)

8. M. Ayre, A. Nafalski, Proceedings of the 30th ASEE/IEEE Frontiers in Education Conference, 18-21 (2000)

9. B. Samsiah, WAHANA Akademik, 3(1), 47-53 (2004)

10. N. Hativa, Teaching for effective learning in higher education, (Netherlands: Kluwer Academic Publishers, 2000)

11. R. M . Felder, J. Spurlin, Int. J. Eng. Edu., 21(1), 103-112 (2005)

12. H.S. Fry, S. Ketteridge, S. Marshall, A handbook for teaching and learning in higher education: enhancing academic performance, 8-26 (Great Britain: Kogan Page Limited, 2009)

13. B. Uğur, B. Akkoyunlu, S. Kurbanoğlu, Edu. Info. Techno., 1-19. http://doi.org/10.1007/s10639-0099109-9 (2011)

14. N. Moussa, Inst. Learn. Styles J., 1, 19-27, http://www.auburn.edu/academic/education/ilsrj/Jo urnal Volumes/Fall 2014 Vol 1 PDFs/Learning Styles Nahla Moussa.pdf (2014)

15. L. F. Capretz, Int. J. Com. Info. Sc., 4(1), 46-49 (2006)

16. R. M. Felder, L. K. Silverman, Eng. Edu., 78(7), 674-681 (1988)

17. J. W. Wood, Teaching students in inclusive settings: adapting and accommodating instructions (United States of America: Pearson Education, 2006)

18. H. Broberg, P. Lin, K. Griggs, J. Eng. Techno., 25(1), 10-17 (2008)

19. W . Ni, Y.Y. Koh,M. W. Khin, International Conference on Teaching and Learning: Achieving Excellence in Education Through Quality teaching and Learning. http://ictl.intimal.edu.my/ictl2007/proceeding/Full _Paper/3C-06-Paper\%2090\%20(Malaysia).doc (2009)

20. S. L. Franzoni, S. Assar, Edu. Techno. Soct., 12(4), 15-29 (2009)

21. E. Palou, J. Food Sc. Edu., 5(7), 51-57 (2006) 
22. M. S. Zywno, M. F. Stewart, M. F, European Society for Engineering Education, Portugal, (2007)

23. H. Dermikan, O. O. Demirbas, Proc. Soc. Beha. Sc., 2(2), 1390-1394 (2010)

24. M. E. Roig, The relationship between learning style preference and achievement in the adult student in a multicultural college, (Doctor of Education Thesis, Walden University, 2008)

25. P. Prasanthi. An exploratory study of undergraduates' learning styles, (Doctor of Education Thesis, Auburn University, 2008)

26. R. A. Boondao, A. J. Hurst, J. I. Sheard, Int. J. Human Soc. Sc., 4(9), 691-695 (2009)

27. R. Liu, X. Qiao, Y. Liu, The Arizona Working Papers on Second Language Acquisition and Teaching 13, 77-91 (2006)

28. Juliawati Ibrahim. Gaya pengajaran guru bahasa daerah Hulu Langat: satu kajian tinjauan. (Projek penyelidikan Ijazah Sarjana Pendidikan, Fakulti Pendidikan, Universiti Kebangsaan Malaysia, 2006)

29. Shindler, J., Teaching for the success of all learning styles: five principles for promoting greater teacher effectiveness and higher student achievement for all students http://www.calstatela.edu/faculty/jshindl/ls/5princi ples.htm (2005)

30. A. C. Sinha, L. C. Sadorra, A primer on ESP for teachers of English, (Manila: De La Salle University Press, 1991)

31. M. S. Zywno, American Society for Engineering Education Annual Conference and Exposition. Organised by the American Society for Engineering Education Annual Conference and Exposition, Tennessee, 22-25 June, (2003)

32. T. A. Litzinger, S. H. Lee, J. C. Wise, R. M. Felder, J. Eng. Edu., 96(4), 309-319 (2007)

33. A. F. Grasha, Teaching with style: a practical guide to enhancing learning by understanding teaching and learning styles, (United States of America: Alliance Publishers, 2002)

34. A. F. Grasha, The Professional \& Organizational Developmental Network in Higher Education, 7(5) http://www.podnetwork.org/publications/teachinge xcellence/95-96/V7,\%20N5\%20Grasha.pdf (1995)

35. A. Kolmos, J. E. Holgaard, J. E., Learning styles of science and engineering students in problem and project based education. SEFI 2008 Annual Conference. http://www.sefi.be/wpcontent/abstracts/1243.pdf (2008)

36. K. M. Ismail, Puteh, S. Mohamed, A preliminary study on the learning style of civil engineering engineering students in Malaysia. Proceedings of the International Conference on Engineering Education (ICEED), 87-91 (2009)

37. I. A. Zualkernan, J. Allert, G. Z. Qadah,., IEEE Transactions on Education, 49(4), 443-450 (2006)

38. J. Larsen, P. R. McCright, G. Weisenborn, Proceedings of the 2004 American Society for Engineering Education Annual Conference \& Exposition, USA. http://soa.asee.org/paper/conference/paperview.cfm?id=20229 (2004)

39. P. R. Burden, D. M. Byrd, Methods for effective teaching: Meeting the needs of all students. (United States of America: Pearson Education Inc, 2010)

40. A. Ganesh, U. P. Ratnakar, SCMS Journal of Indian Management, 11(3), 26-37 (2014)

41. M. P. Lee, S. M. Thang, M. K. Radha, Nambiar, The Social Sciences, 11(12), 2977-2982 (2016)

42. S. Meera, L. Sudak, P. Egberts, Mapping conventional teaching methods and learning styles in engineering dynamics. In American Society of Engineering Education Annual Meeting in Engineering Dynamics (2016)

43. R. M. Felder, E. R. Henriques, Foreign Language Annals, 28(1), 21-31 (1995)

44. B. L. Brown, Teaching style vs. learning style, (United States of America: Clearinghouse on Adult, Career and Vocational Education, 2003)

45. B. Joyce, M. Weil, E. Calhoun, Models of teaching. (United States of America: Pearson Education Inc, 2011)

46. C. K. Lee, S. S. Manjit, Edu. Techno. Soc., 18 (3), 266-281 (2015) 